\title{
TERMINOLOGICAL APPARATUS IN THE FIELD OF BIOECONOMY
}

\author{
P. Branzova* \\ Department "Regional and Sectoral Economics", Economic Research Institute at \\ Bulgarian Academy of Sciences, Sofia, Bulgaria
}

\begin{abstract}
The purpose of the report is to provide a terminological device in the field of bio-economy. Scientific and popular definitions for it are emerging and systematized. A historical review is made and the prospects for bio-economics are outlined.
\end{abstract}

Key words: bio, economy, green technologies, definitions.

\section{INTRODUCTION}

Food security, energy supply, and climate change are among the biggest global challenges in the next future.Radical changes in the economy are necessary to face these challenges. The Bioeconomy, including the deployment of various biorefining strategies, represents one of the pillars for a more sustainable global development. In 2012, the European Union (EU) and the USA adopted their respective strategies on Bioeconomy. Since then a number of national and international agendas have been developed. The Joint Research Centre (JRC), as coordinator of the European Commission's Knowledge Centre for Bioeconomy (BKC), in collaboration with the BiobasedIndustries Joint Undertaking (BBI JU), the Technology Collaboration Programme (TCP) Bioenergy of the International Energy Agency (IEA), and with input from other stakeholders, undertook a survey onthe Bioeconomy progress statusin the EU Member States.IEA Bioenergy Task42cooperated in this surveyby in particular extendingthe analysisto extra EU countries, and providing a database of the recentlydeveloped biorefineries.

\section{Exposition}

The high level of political interest in the bioeconomy is based on a number of potential

\footnotetext{
*Correspondence to: Petia Branzova, Department "Regional and Sectoral Economics", Economic Research Institute at Bulgarian Academy of Sciences, 3 Akakov Str., Sofia, e-mail: petia.branzova@gmail.com
}

benefits: reducing greenhouse gas emissions, reducing dependence on fossil resources and improving food security. It is also expected to stimulate the bioeconomy to create employment and create new markets for nonfood goods, thus benefiting rural development. It is estimated that over $90 \%$ of petroleum products could be replaced by alternatives on a biological basis. The challenge is rather to increase the scale of activities.

The term itself is not exactly defined. The content of the bioeconomy depends on the user's perspective and the context in which it is used. It is therefore not surprising that political papers, as well as scientific papers, give a lot of space to discuss what it means. According to the European Commission's (EC) Bioeconomy Strategy, the bioeconomy is defined as "the production of renewable bioresources and the conversion of these resources and waste streams into value-added products such as food, feed, bio-based products and bioenergy. (1) Biomeconomics encompasses all sectors and systems that rely on biological resources (animals, plants, microorganisms and derived biomass, including organic waste), their functions and principles. It includes and connects: the terrestrial and marine ecosystems and the services they provide; all sectors of primary production that use and produce biological resources (agriculture, forestry, fisheries and aquaculture); and all economic and industrial sectors that use biological resources and processes to produce food, feed, bio-based products, energy and services. 
FAO defines bioeconomy as knowledge- based production and use of biological resources, biological processes and principles of sustainable provision of goods and services in all economic sectors. (2) It includes three elements:

- Use of renewable biomass and efficient bioprocesses to achieve sustainable production; - Use of enabling and converging technologies, including biotechnology; - Integration between applications such as agriculture, healthcare and industry.

According to the OECD, "Bioeconomy can be seen as a world in which biotechnology contributes to a significant share of economic output. The emerging bioeconomy will probably include three elements: -

- $\quad$ Using advanced knowledge of genes and complex cellular processes to develop new processes and products;

- $\quad$ the use of renewable biomass and efficient bio-processes to support sustainable production;

- Integrating biotechnological
knowledge and applications across sectors. "(3)

"Bioeconomy is knowledge-based production and use of biological resources to provide products, processes and services in all economic sectors within a sustainable economic system." Definition of the Bioeconomy Council.

The bioeconomy or bio-base economy is a new model for industry and the economy. It involves the sustainable use of renewable biological resources for the production of food, energy and industrial goods. It also uses the untapped potential stored in millions of tones of bio-waste and residual materials.

Bioeconomics involves the fullest possible destruction of plants in their constituent parts and their transformation into valuable materials. It is expected that this challenge will be met in the future by large bio-refineries with very coordinated steps in the process.

\section{Definition by counties}

\section{Germany}

Bioeconomy is the knowledge-based production and utilization of renewable resources in order to provide products, processes and services in all economic sectors, within the framework of an economic system that is viable for the future.(4) According to the bioeconomy progress report, German bioeconomy contributed $6 \%$ of the overall economic value added in 2010. The bioeconomygrew by $22 \%$ between 2002 and 2010, while the economy as a whole grew by $16 \%$. If the weight of the bioeconomy is considered on the basis of the employment ratio, the significance of the bioeconomy is doubled compared to the value added.

\section{France}

The bioeconomy encompasses the whole range of activities linked to bioresource production, useand processing. The purpose of bioresources is to provide a sustainable response to the need of food and to part of society's requirements for materials and energy, as well as providing society with ecosystem services. Biobased products are defined as products deriving entirely or partially from bioresources. (5)

\section{Italy}

The bioeconomy comprises those parts of the economy that use renewable biological resources from land and sea -such as crops, forests, fishes, animals and micro-organisms to produce food, materials and energy (6). Thus, it includes primary production sector suchas agriculture, forestry, fisheries and aquaculture -and industrial sectors using and/or processing biological resources, such as the food and pulp and paper industries and parts of the chemical, biotechnological and energy industries. The bioeconomy refers to the set of economic activities relating to the invention, development, production and use of biological products, services and processes acrossfour macro-sectors: 1 -Agrifood; 2 Forestry; 3 -Biobased industry (bioenergy; biofuels; chemical intermediates); 4 -Marine.

\section{United Kingdom}

UK's definition of bioeconomy is being developed as part of the creation of the UK Bioeconomy Strategy (7). The current definition is: All economic activity derived from biobasedproducts and processes which contribute to the sustainable and resourceefficient solutions to the challenges we face in food, chemicals, materials, energy production, health and environmental protection. The bioeconomy is the production of biomass (organic matter derived from living, or recently living organisms) and the conversion of renewable biological resources into valueadded products, such as food, biobasedproducts and bioenergy. In Scotland, it is about using biological resources or 
bioprocesses to make new products such as food, materials and energy as well as adding value to waste materials. Food waste is a significant source of carbon emissions; and a more circular approach to the beer, whisky and fish sectors alone could lead to potential savings of half a billion pounds per year. (8)

\section{Spain}

The bioeconomy is the set of economic activities that obtain products and services, generating economic value, making efficient and sustainable use of resources of biological origin as fundamental elements. Its objective is to produce and market food, along with forestry products, bioproducts and bioenergy obtained by physical, chemical, biochemical or biological processing of organic matter not destined for human or animal consumption and involving processes which are respectful of the environment, along with the development of rural areas (9)

\section{Sweden}

Sustainable production of biomass to enable increased use in a number of social sectors.(10) The aim is to reduce climate impact and the use of fossil raw materials. Increased value added of biomass while minimizing energy consumption and nutrition and energy is taken from the end products optimizing the value and contribution of ecosystem services to the economy.

\section{Austria}

Step by step fossil resources will be replaced by renewable raw materials in order to provide new products, services and energy. Furthermore, waste matter is used again in the value cycle.(11) In the processes for bioeconomy policies/strategies more comprehensive definitions are discussed.

\section{Finland}

Bioeconomy refers to an economy that relies on renewable natural resources to produce food, energy, products and services. The bioeconomy will reduce our dependence on fossil natural resources, prevent biodiversity loss and create new economic growth and jobs in line with the principles of sustainable development. The bioeconomy is not a new industry; it is a combination of several primary production and refining sectors and end product markets. Typical features of the bioeconomy include the use of renewable, biobasednatural resources, environmentally friendly clean technologies and efficient recycling of materials. It is justified to refer to the transition from a fossil economy to a bioeconomy as the new wave of economic development.(12)

\section{Greece}

Bioeconomy is considered as a new production system, where the needsfor fuel, food and feed are covered by renewable organic sources. Bioeconomy in Greece is supported under different thematic areas within RIS3 (Smart Specialization Strategies).

\section{Croatia}

Bioeconomy strategy has not yet been created. Based on Croatian s Smart specialization Strategy (2016-2020) [27]the term "bioeconomy" canbe defined as economy that comprises primary agriculture, fishery, and aquaculture and other economies that use renewable biological resources from landand sea.(13)

\section{Latvia}

Bioeconomy covers those parts of economy where renewable bio-resources (plants, animals, microorganisms etc.) are used in the production of food, feed, industrial products and energy in a sustainable and wellconsidered way.(14)

Estonia

Bioeconomy means the production of sustainable biomass and conversion of biomass into food, feed, energy and other bioproducts; Bioeconomy means adding value to the sustainable utilization of biomass in interrelated economic activities

\section{Norway}

The Government's bioeconomy policy targets sustainable, effective and profitable production, extraction and use of renewable, biological resources into food, feed, ingredients, health products, energy, materials, chemicals, paper, textiles and numerous other products. The use of enabling technologies like biotechnology, nanotechnology and ICT are in addition to conventional disciplines like chemistry essential for the development of a modern bioeconomy.(15)

\section{Turkey}

In Turkey, bioeconomy is defined as the contribution of biotechnical applications on economy aimed the producing of goods which are sensitive to the environment and health and also aimed sustainable utilization of renewable biological resources 


\section{Australia}

The Australian Government generally defines the bioeconomy as "the sustainable production and conversion of biomass for a range of food, health, fibre and other industrial products as well as energy". (16)

The bioeconomy is intended as combination of knowledge and innovation in biosciences, with other technology sectorssuchas chemistry, engineering, computer science and nanotechnologies. (17)

\section{USA}

The bioeconomy is defined as "sustainable use of domestically produced renewable biomass for fuels, products, and power". The Federal Activities Report (2016) describes it as "global industrial transition of sustainably utilizing renewable aquatic and terrestrial biomass resources in energy, intermediate, and final products for economic, environmental, social, and national security benefits". (18)

The Netherlands, Denmark, Belgium, Estonia and Slovenia use the definition given by the EC. Switzerland adopts the OECD definition. In Poland, Portugal, Iceland, Luxembourg, the Czech Republic, Hungary, Lithuania, Cyprus, Romania and Bulgaria, there is no normative document defining the term bioeconomy yet.

At present, only Germany, France, Spain, Ireland, Italy, Latvia, Finland and Malta have devoted national strategies to bioeconomy at national level. Six EU countries have developed strategies, while the other 13 have other policy initiatives or related strategies at national level. In Bulgaria, the national strategy is being developed a regional strategy for the Stara Zagora region.

\section{CONCLUSION}

The limited biological resources and ecosystems of our planet are essential to feeding people, providing clean water and affordable and clean energy. A sustainable bioeconomy is essential to tackling climate change and land and ecosystem degradation. It will respond to the rising demand for food, feed, energy, materials and products due to the growing population of the world and will reduce our dependence on non-renewable resources.

Establishing a sustainable and circular bioeconomy will increase the competitiveness of the bio-economy sectors and help create new value chains in Europe while improving the overall state of our natural resources. Such a bio-economy will rely on and take advantage of the sustainable renewable resources available in the country as well as advances in science, technology and innovation, integrating the physical, digital and biological world into some of the most important sectors and industries in the EU.

\section{ACKNOWLEDGMENTS}

This work was supported by the Bulgarian Ministry of Education and Science under the National Research Programme ,Healthy Foods for a Strong Bio-Economy and Quality of Life" approved by DCM \# 577/ 17.08.2018";.

\section{REFERENCES}

1. https://ec.europa.eu/research/bioeconomy/i ndex.cfm?pg=policy;

2. http://www.fao.org/energy/bioeconomy/en/;

3. https://read.oecdilibrary.org/economics/the-bioeconomy-to2030/defining-the-

bioeconomy_9789264056886-3en\#page 14;

4. Germany National Policy Strategy an Bioeconomy; German Bioeconomy Council available at:http://www.pflanzenforschung.de/files/4 514/7886/1937/German_bioeconomy_Strat egy_2030.pdf;

5. BMEL (2016): Fortschrittsbericht zur Nationalen Politikstrategie Bioökonomie. Berlin: German Ministry of Food and Agriculture.

6. Republic of France. (2017). A Bioeconomy Strategy for France: Goals, issues and forward vision. Available at http://agriculture.gouv.fr/telecharger/83595 ?token $=4 \mathrm{~b} 2095 \mathrm{fafe} 14 \mathrm{f075309} \mathrm{cc} 193 \mathrm{dda} 53 \mathrm{~d}$ 70[last access 03/10/18]

7. Bonaretti, P. et al. (2017). Bioeconomy in Italy: A unique opportunity to reconnect the economy, society and the environment. Available at http://www.agenziacoesione.gov.it/opencm s/export/sites/dps/it/documentazione/NEW S_2016/BIT/BIT_EN.pdf [last access 10.01.18].

8. The Scottish Government (2016): Making Things Last A Circular Economy Strategy for Scotland. Available at: https://www.gov.scot/Resource/0049/00494 471.pdf

9. The Scottish Government (2016): A Manufacturing Future for Scotland. Available at https://beta.gov.scot/binaries/content/docu ments/govscot/publications/corporate- 
report/2018/09/a-manufacturing-future-forscotland-action-plan/documents/amanufacturing-future-for-scotland/amanufacturing-future-forscotland/govscot\%3Adocument?forceDown load=true

10. Spanish Ministry of Economy, Industry and Competitiveness (2015). The Spanish Bioeconomy Strategy: Horizon 2030. Available at http://bioeconomia.agripa.org/downloaddoc/102159 [last access 05.04.18].

11.The Swedish Research Council for Environment, Agricultural Sciences and Spatial Planning: ReportSwedish Research and Innovation Strategy for a BiobasedEconomy (2012). Available at: http://www.formas.se/PageFiles/5074/Strat egy_Biobased_Ekonomy_hela.pdf. [last access 03.10.18]

12.Bioeconomy Austria -BIOS Science Austria. Available at: https://www.bioeconomy-austria.at/en/ [last access 03.10.18]

13.The Finnish Bioeconomy Strategy (2014). Available at :http://www.bioeconomy.fi/facts-andcontacts/finnish-bioeconomy-strategy/ [last access 03.10.18]

14.Croatian Smart Specialisation Strategy (2016-2020). Available at http://s3platform.jrc.ec.europa.eu/document s/20182/222782/strategy_EN.pdf/e0e7a3d7
BRANZOVA P. -a3b9-4240-a651-a3f6bfaaf10e[last access 03.10.18]

15.Ministry of Agriculture of the Repubic of Latvia. (2017). Latvian Bioeconomy Strategy 2030. Available at :http://tap.mk.gov.lv/lv/mk/tap/?pid=40433 $525 \&$ mode $=$ mk\&d ate $=2017-12-19$ [last access 13.03.18].

16. Norwegian Ministry of Trade, Industry and Fisheries. (2016). Familiar resources undreamt of possibilities: The Government's Bioeconomy Strategy. Available at https://www.regjeringen.no/contentassets/3 216 0cf211df4d3c8f3ab794f885d5be/biookono mi-eng-kortversjon_uu.pdf [last access03.10.18]

17.Australia FAO 2018 at: http://www.fao.org/3/I9580EN/i9580en.pdf [last access02/02/2018]

18.USDA 2015 Golden, J.S., Handfield, R.B., Daystar, J. and, T.E. McConnell (2015). An Economic Impact Analysis of the U.S. Biobased Products Industry: A Report to the Congress of the United States of America. A Joint Publication of the Duke Center for Sustainability \& Commerce and the Supply Chain Resource Cooperative at North Carolina State University. Available at

https://www.biopreferred.gov/BPResources /files/EconomicReport_6_12_2015.pdf[last access 03.10.18] 